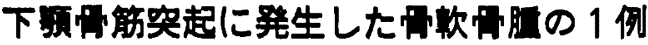

作田正戟・原田尚粑・小川蚂

营原利夫・石田 武*

\section{Osteochondroma of coronoid process of mandible: A case report}

\author{
Masayoshi Sakuda - Hisanori Harada - Teruaki Ogawa \\ Toshio Sugahara - Takeshi IshidA*
}

\begin{abstract}
Osteochondroma or osteocartilageous exostosis is a common disease in the osseous tissue.

However, osteochondroma occurring in the coronoid process is relatively rare, and is interesting in differential diagnosis when resulting from trauma, developmental malformation, temporomandibular dysfunction syndrome and others, and causality of this disease.

This paper described a female patient, 54 years old, whose presenting problem was a chronic limitation of mandibular movement caused by the osteochondroma of coronoid process, and she was treated surgicaly. The problem disappeared following the operation, and the prognosis is favorable.
\end{abstract}

Key words: osteochondroma, coronoid process, trismus

楮言

下類骨筋突起に発生する骨軟骨睡は比較的まれなるの であるのみならず，預関節症などの各種他疾患と爁別を 要することがあり，䠛床的に興味がある.

今回，われわれは右下預筋突起部に発生した骨軟骨腫 の 1 例を経耠した．その臨床経過，病理組織像などを報 告するとともに，文献的に症例を検討し，若干の知見を 得たので報告する.

症

例

\section{患 者: 54歳 女性}

大阪大学学部口腔外科学第 2 講座 （主任：作田正義救授）

* 大阪大学歯学部附属病院检查部 （部長：作田正義部長）

2 nd Department of Oral \& Maxillofacial Surgery, Osaka University Faculty of Dentistry (Chief: Prof. Masayoshi Sakuda)

* Clinical laboratory, Hospital attached to the Osaka University Faculty of Dentistry (Chief: Prof. Masayoshi Sakuda)

受付日：昭和60年 9 月 13 日
初 診：昭和56年12月口日.

主 訴: 開口障害.

家族歴：特記事項はない。

既往症 : 19 筬の時肺浸润. 急性肝炎に陮患するも完 治，その他特記すべき事項はない。

現病歴：昭和 45 年頃より，開口時右側䫇関節附近に弾 撥音が発現したが，その他の自覚㱏状を認めなかったの

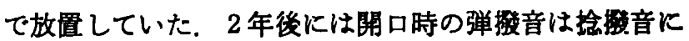
変わり, 同時に右頉骨部附近に軽度の腫脹を覚えた。し かし，開閉口時の疼痛，自発痛は認めていないささらに 1 年後飞至り，徐々飞開口障害，荤引痛，下頻左右運功 の困難が出現し始めたため, 近所の整形外科, 口腔外科 を受診し，右側䫇関節腔内への薬郕注射（副堅皮貿ホル

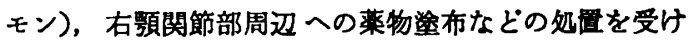
た.しかし，治痹の傾向がなく，方向感覚異常などの副 作用がみられたため, 数回の注射で中止した. さらに中 国針治療などを行った結果, 右側煩骨部の畽脹感はやや 軽減，また開口障害のわずかな改善を認めたが，不十分 であったため，近位歯科の紹介により本院を受診した。

現 症

全身所見：体格は中程度，栄養状熊良好，体重 $50 \mathrm{~kg}$, 身長 $154 \mathrm{~cm}$.

臨床検查所見：CRP $2(+)$, RAHA 20 dils を示す 以外は特に異常值を認めない. 


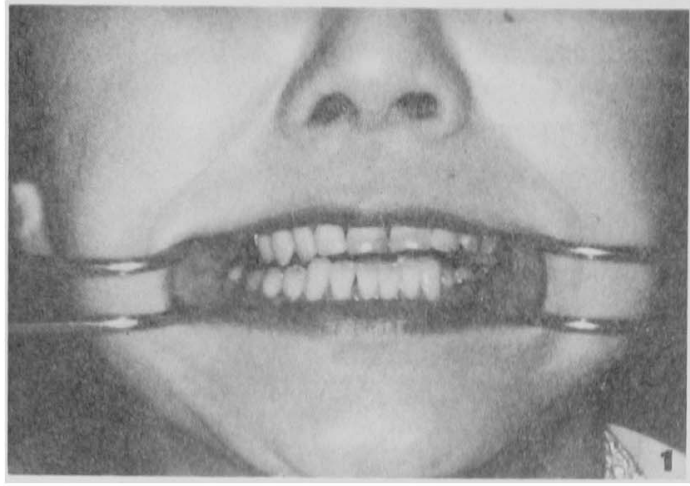

军 1 闸口状熊

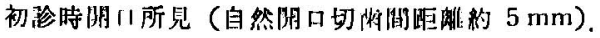

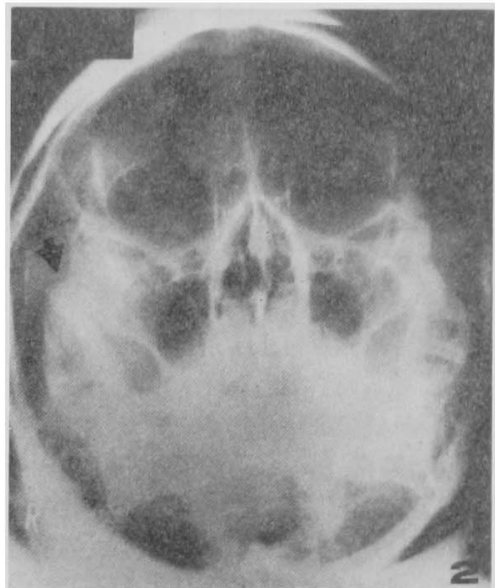

写真 2 腄㳟X線所見 (Walers 沙)

、右㑡漩突起部付近にX線不透過像の存在を羿める。

局所所見：顔貌は左右非対称で，右側耳介前方部にや やび慢性尰脹を認めるが，これを被う皮成は正常色を呈 する，開口状態は自然開口切歯間距離約 $5 \mathrm{~mm}$, 強制開 口切歯間距離䄪 $15 \mathrm{~mm}$ である（写真 1). 開口時右側煩 部に捻撥音を認めるが疼痛はない，咬合関係は正常であ った．所属リンパ節にも異常は認められなかった。

X線所見：初診時 Schüller 法によるX線写孛では、特 に频関節に異常は認めなかった，しかし Waters 法によ るX線写真に打いて，右側解㔖起部附近に異常陰影像を 認めた，軸位写真所見では右側煩骨弓附近に異常所見， すなわち煩骨弓附近一帯にX線不透化像，頓骨弓の骨膨 隆を思わせる所見と，放射状に走る trabeculation 等の 所見が得られた．そこで断層撮影による精查で右觔突起 の延長扣よび䫒著な骨硬化像，またその尖端部に trabeculation を有する像を確認することができた，以上のレ ントダン所見により右側筋突起に存在する骨腫と判断し た (写真 2,3 ).

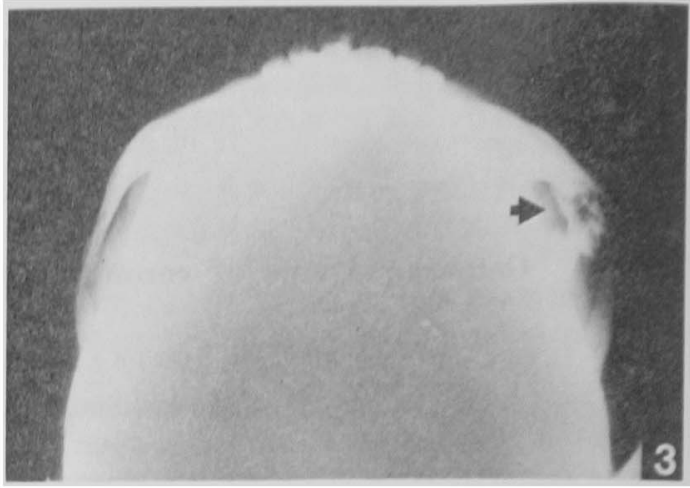

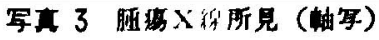

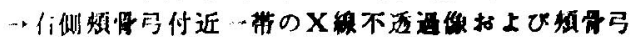
の骨腿陵像。

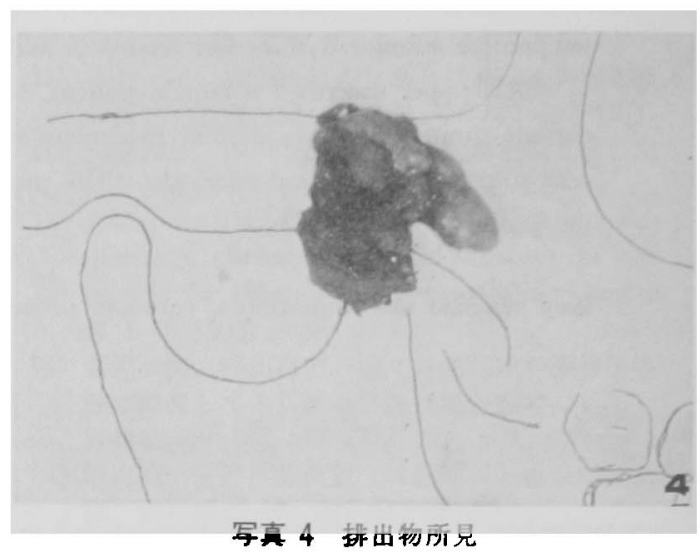

摘出物は表面白色滑讯で，大きさは $20 \times 10 \times 8 \mathrm{~mm}$

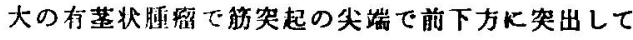
いた。

処 置：炤和57年 6 月曰日，释乘插管による GOF 全 身麻酔下において腫瘤摘出術を施行した。 modifiedVelpau の切開線を用い術野を明視下においた，咬笳前 縁部を上部において一部切断, 筋突起の一部と隀场塊の 一部を的露出させた。侧頭筋の一部を䟝離し，筋突起部附 近で切断した．尰瘤に接する䫅骨弓内面は压迫により吸 収变形を是していた，衍後 2 週間目に開口度は $2.5 \mathrm{~cm}$ 可能となった. 術後 1 年後開口度は $3.1 \mathrm{~cm}$ となり, 開 口痛もなく開口時の雑音当消失している.

摘出物肉眼所見：摘出物は表面白色滑沢な $20 \times 10 \times 8$ $\mathrm{mm}$ 大の有茎状の腫䍇で，山凸不正を示し，筋突起の尖 端で前下方に突出していた，割面をみると浅層は軟骨様 を呈し，潹層は海綿骨様多孔質を示していた（写真 4).

病理組織所見：腫瘤の最表面には線稚性被膜が存在 し，その下層には比較的厚い軟骨組織（軟骨帽）が続 く.この層は表面に近い所で纤若な軟骨組織よりなり， 下層に至るほど成熟したものになっている。この軟骨幅 


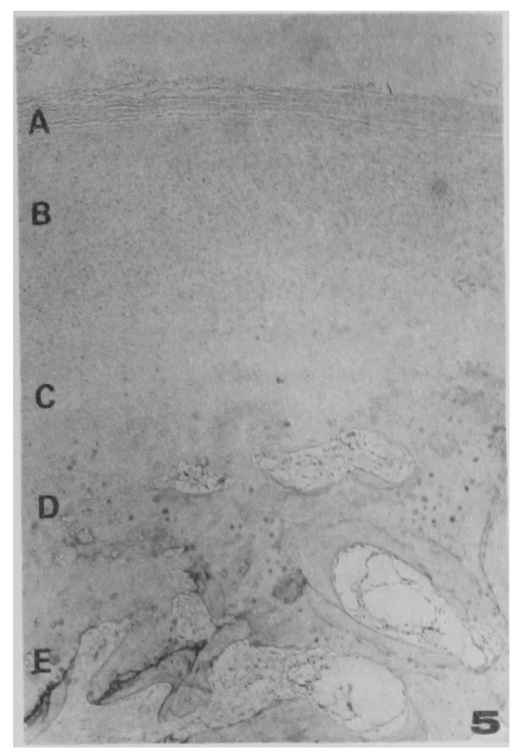

写真 5 病理組臌所見
A：肥厚した線䊒性被膜
B . 軟骨帽
C：第一次骨梁㻺
$\mathrm{D}$ : 海楾骨梁屡
E：正常な骨組織

に続き成熟した骨梁の形成があり，海綿骨，比較的豊富

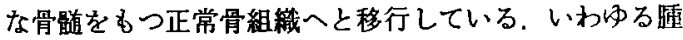

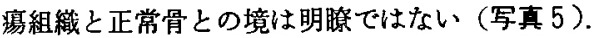

診断名：骨軟骨腫（骨軟骨性外骨腫）。

$$
\text { 考 察 }
$$

䫑関節症の主徽候は開口障害, 顥関節部の閉閉口時の 雑音, 開閉口時の頡関節部またはその周辺組織の疼痛で ある1). 今回，われわれが経験した症例は長期間にわた り開口障害と䫑関節部前方の雑音を主徽とし，明確な炎 症症状を欠く既往をあつものであった。したがって臨休 的には影関節症がまず疑われ，当院来院までにも他院に おいて䫑関節症として処置されていた。しかし，本症例 は上記のような所見以外汇頻関節部よりやや前方に膨隆 を認め，精査すると雑音るこの部分より発生しているこ とが聴取できた。他報告をみても，筋突起部に 発生し た骨軟骨腫症例の多くは顿骨弓附近に膨隆を認めて拉 $\eta^{2,3)}$ ，重要な所見といえる。

骨軟骨腫自体はそれ活どまれなるのではなく，全骨腫 湯中の約半数を占めるといら報告るある ${ }^{4,5)}$ ．四肢の長 管骨とくに大腿骨下端，脛骨上端部は好発部といわれる が5)，下靧骨筋突起での発生は少なく，われわれの涉併 した範囲では自験例を含め，国の内外で37例を数えたに

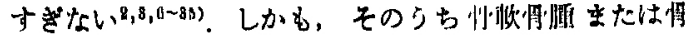

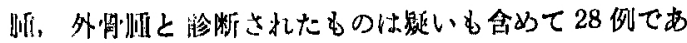

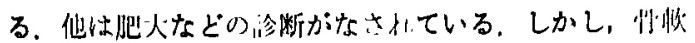

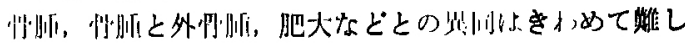

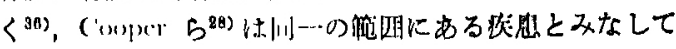
Wる.

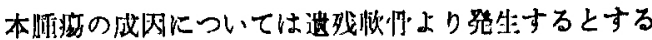
むの ( JafTc ${ }^{377}$. Thoma \& (ioldman ${ }^{38)}$ Mils $5^{38)}$ ),

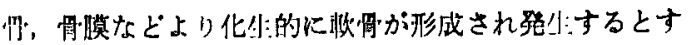
るもの( 1 icht(enstein ${ }^{40)}, x_{1} \|^{41)}$, (jesiclul(c \& Copeland ${ }^{42)}$,

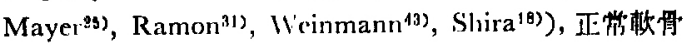

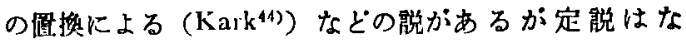

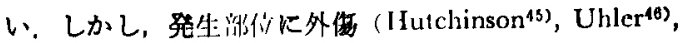

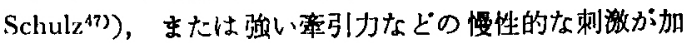
わるとその発生をより容易にする可能性がある。

Shackelford \& Brown ${ }^{6,1}$ ) は筋突起拊着する例顽筋 の旁引力が関与して骨・职骨・の增殖を唀導すると考えて 打り，さらに下顎関節頇には注注全面に杴骨が存在する か，外仪翼突筋の附不する部分に本症の発生が多い(2)井 实もこのことを支持すると思われる。

一般的組䄉像は，肥厚した被膜，顿骨怕，第一次骨梁 層，海綿骨梁層と䋨き，正常な骨組織へと移行してお。 り，㳄骨帽は幼若な軟骨細胞が增殖し，その下部に成熟 した骨梁の形成を認める（われわれの報告した症例むは ぼ同様の形態を示していた)．本病变が若年者に発生し た時よりる高跉者にみられたものの方が瑟性化する佰向 がらかがえ，その理由として，㪀骨帽が長期にわたり遺 残すると軟骨肉近へ枟化することがあると， Lichtenstein ら ${ }^{40)}$ は発表している。国立ガンセンター骨顿部腫 湯クルーブはに打いては多発性のものに悪性化する率 は，30 歳以後で骨杴骨嗹の5ち1\%であると述へてい る.

さて，本症例を含め施突起飞発生した骨歌骨腫症例 37 例をみると，性別では男性26例，女性11例と男性に多い （表 2）．また発症年龄をみると19藏以下が14例と最る多

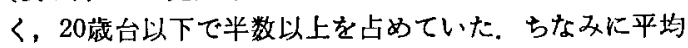
年㱓は28藏である。一方，これを筫関節部のそれと文献

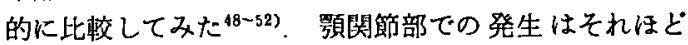
ま机なるのではなく，Bruce らら3)は文献的に症例を集計 し，150例以上の報告があると記載している. Blomquist ら 54 《 100 例以上の症例を文献的に集めているが，しか し，骨軟骨畽（骨軟骨性外骨隀）は少ないと報告し，ま た性差はなかったと述べている，同様のことを Jaffe ${ }^{377 ，}$ Lichtenstein ${ }^{40)}$ む述べている. 川村ら ${ }^{30)}$ は影関節突起に 発生した骨軟骨性外骨腫（骨軟骨腫）とそうでないるの を文献的に区別し，56例中25例を骨軟骨性外骨腫とし， 他の31例を先天性過形成とした．他の報告 $48,49,51,52) を$ せてみると外骨腫または骨軟骨腫と診断されたるのの初 診時年龄は平均で38歳であり，30歳台が最る多かった。 
麦 1 過去に発决された症侧とその断名

\begin{tabular}{|c|c|c|c|c|c|}
\hline & 䢁告 橧 & 西糜 & 性 别 & 年战 & 断名 \\
\hline 1 & Shackelford \& Brown ${ }^{6)}$ & 1943 & $\operatorname{man}$ & 15 & Osteochondroma \\
\hline 2 & Shackelford \& Brown ${ }^{6)}$ & 1943 & $\operatorname{man}$ & 19 & Osteochondroma \\
\hline 3 & Brandt $t^{\text {) }}$ & 1943 & woman & 37 & Exostosis \\
\hline 4 & Hallam ${ }^{8)}$ & 1947 & $\operatorname{man}$ & 18 & Exostosis \\
\hline 5 & Shackelford \& Brown' & 1949 & $\operatorname{man}$ & 38 & Osteochondroma \\
\hline 6 & Brailsford 11$)$ & 1952 & $\operatorname{man}$ & 24 & Osteochondroma \\
\hline 7 & Rowe $e^{10)}$ & 1952 & $\operatorname{man}$ & 15 & developmental hyperplasia \\
\hline 8 & Rowe $^{10)}$ & 1952 & $\operatorname{man}$ & 15 & developmental hyperplasia \\
\hline 9 & Holmes ${ }^{12)}$ & 1956 & $\operatorname{man}$ & 38 & Osteochondroma \\
\hline 10 & Dingman et al ${ }^{13)}$ & 1957 & $\operatorname{man}$ & 27 & Osteochondroma \\
\hline 11 & Levine ${ }^{(4)}$ & 1957 & woman & 73 & Osteochondroma \\
\hline 12 & Vanizine $^{(s)}$ & 1957 & $\operatorname{man}$ & 30 & Exostonis \\
\hline 13 & Antoni et al ${ }^{16)}$ & 1958 & $\operatorname{man}$ & 29 & Osteochondroma \\
\hline 14 & Dap \& Friedman ${ }^{17)}$ & 1958 & $\operatorname{man}$ & 30 & Osteochondroma \\
\hline 15 & Shira ${ }^{18)}$ & 1958 & $\operatorname{man}$ & 14 & developmental anomaly \\
\hline 16 & Lewars ${ }^{10)}$ & 1959 & $\operatorname{man}$ & 15 & Osteoma \\
\hline 17 & Lebo $^{20)}$ & 1961 & $\operatorname{man}$ & 18 & Osteochondroma \\
\hline 18 & Mohnac ${ }^{21)}$ & 1962 & $\operatorname{man}$ & 18 & Exostosis \\
\hline 19 & Lyon 22$)$ & 1963 & $\operatorname{man}$ & 27 & Enlargement \\
\hline 20 & Allan \& Reid ${ }^{28)}$ & 1967 & $\operatorname{man}$ & 22 & Exostosis \\
\hline 21 & Allan \& Reid ${ }^{23)}$ & 1967 & woman & 32 & Exostosis \\
\hline 22 & Fitzpatrick ${ }^{24)}$ & 1970 & $\operatorname{man}$ & 27 & Enlargement \\
\hline 23 & Meyer ${ }^{25)}$ & 1972 & $\operatorname{man}$ & 10 & Osteochondroma \\
\hline 24 & 西嶋 $5^{26)}$ & 1972 & $\operatorname{man}$ & 25 & Exostosis \\
\hline 25 & Allan \& Scott ${ }^{27)}$ & 1974 & woman & 43 & Osteochondroma \\
\hline 26 & Cooper ${ }^{28)}$ & 1974 & woman & 43 & Osteochondroma \\
\hline 27 & James et $\mathrm{al}^{28)}$ & 1974 & woman & 52 & Osteochondroma \\
\hline 28 & 武田 $5^{30)}$ & 1975 & woman & 14 & Osteochondroma \\
\hline 29 & Ramon et $\mathrm{al}^{31}$ ) & 1977 & $\operatorname{man}$ & 45 & Osteochondroma \\
\hline 30 & Hecker ${ }^{32)}$ & 1980 & $\operatorname{man}$ & 16 & hyperplasia \\
\hline 31 & 伊藤ら8) & 1981 & woman & 20 & Osteochondroma \\
\hline 32 & Javid ${ }^{33)}$ & 1981 & $\operatorname{man}$ & 23 & hyperplasia \\
\hline 33 & 石井 ${ }^{2)}$ & 1982 & $\operatorname{man}$ & 32 & Osteochondroma \\
\hline 34 & 石井 ら²) & 1982 & woman & 53 & Osteochondroma \\
\hline 35 & Lucaya ${ }^{34)}$ & 1982 & woman & 9 & hyperplasia \\
\hline 36 & Tucker ${ }^{33)}$ & 1984 & $\operatorname{man}$ & 16 & hyperplasia \\
\hline 37 & 作田ら & 1985 & woman & 54 & Osteochondroma \\
\hline
\end{tabular}

また性別でも男性10例に対し，女性20例と女性の方が多 い. Blomquest $5^{54)}$ は下額骨䫫関節突起の肥大は20歳 台の末に症状の出現をみることが多いと述べている．顥 関節部に発生したものの病態，病名は多彩であるため， 単純な比較は問題があるが，表 1 に示すごとく本症例を 含めた 37 例をみると，筇突起部に発症したるのは男性に 多く，年龄的にもやや低年龄期に初診がなされているよ
5に思える．これを骨㜞骨盾（外骨盾を含む）と病名の ついているものに限ってみてるこの值向は变わらない。 Lichtenstein ${ }^{40)}$ は骨軟骨性外骨䜒の発生は，少年期から 青年期にかけてであるとしているが,增生る徐々で, 症状 の発現が遅いため，実際の来院はかなり荤れるすのと思 われる. 頻関節部と筋突起部での本症の発生内容の遣い を考えてみると，影関節症の発生率が女性に多いこと， 
产 2 年路跳布

\begin{tabular}{|c|c|c|c|c|}
\hline & \multicolumn{3}{|c|}{ 筋突起に発生した症例 } & 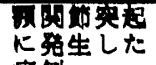 \\
\hline 年毁 & 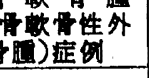 & その他 & 粨 & 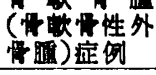 \\
\hline $0 \sim 9$ & 0 & 1 & 1 & 0 \\
\hline $10 \sim 19$ & 8 & 5 & 13 & 1 \\
\hline $20 \sim 29$ & 6 & 3 & 9 & 5 \\
\hline $30 \sim 39$ & 7 & 0 & 7 & 12 \\
\hline $40 \sim 49$ & 3 & 0 & 3 & 8 \\
\hline $50 \sim 59$ & 3 & 0 & 3 & 2 \\
\hline 60以上 & 1 & 0 & 1 & 2 \\
\hline \multirow[t]{2}{*}{ 計 } & 28 & 9 & 37 & 30 \\
\hline & \multicolumn{3}{|c|}{ 平均27.9樀 } & 平均37.9劌 \\
\hline
\end{tabular}

一方筋突起部では側頭筋の筋力，茟引力，作用共の速い と何らかの成連性を有しているのではないかと推測して いろ.

上記の例る含めて，過去に報告されてきた症例の発 見法はX 線検㚗によらねばならない。振影法としては Waters' 法, ortho-pantomo 撮影法, 断層掫影法がよく 用いられる. Holmes ${ }^{12)}, M_{0 h n a c}^{21)}$ らは断周撮影法を， Cooper ${ }^{28)}$, Rowe $^{10)}$ は ortho-pantomo 撮影法を推奖して いるが，尰瘤の明確な存在部位を確認するためには一つ の方法にこだわることなく，数種の方法を用い的確に診 断を下すべきであろう．本症例では Water's 法, 軸位写 真が異常像の判定に有奻であり，CT 像は煩骨弓と能突 起のいずれに発生したるのかを判別するのに役立った.

本症の治療法について述べると，基本的には摘出術が 行われる. 手術法には口外法と口内法があるが，いずれ も一長一短がある。本症例には口外法を用いた。 口外法 は術野が広く, 操作しやすいが, 術後の疲痕が取す大き な問題となる. 顔面神経, stenon 管の障害る可能性と してはあるが，注意して行えばほとんど起こらない.一 方，口内法は術後の審美性にきわめて優れているが，術 野が狭く、畽瘤の状態によっては摘出がきわめて困難な ことがる。ささらに術野に近接する額動脈の損做により 大出血をきたす可能性がある．いずれを選択するかは個 々の症例を検討して決定されることになる，その他留意 する必要があることは，笳突起の切断部位がある．本尰

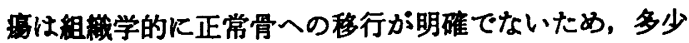
の安全域をみて離断する方が危険が少ない．また側頭筋 の腱の筋突起への附着は比較的広範囲にあるため, 腱の 附着をどこまで剝離切断するかといら問題がある．生理 的には可能なかきりり残存させるべきと考えられるが，本 症発生の成因機序を考えると，健の牫存が再発へつなが る可能性すある。この点については今後の検討に待たな
ければならない。

枯

Anit

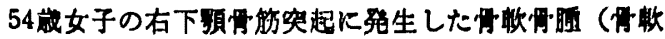

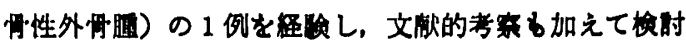
をした，主訴は開口障客で，罚成節症との鑑则の必要な 息者であり，摘出手術により症状の改警がみられた。

なお，本䑳文の要旨は昭和57年 7 月 10 日，第 3 回孫间 節研究会(東京) において発衣した。

\section{引用 文 嗝}

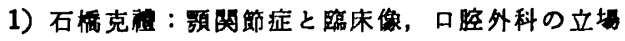
から. Dental Diamond 7: 36-41 1982.

2）石井純一，天篮光雄，他：下罰骨筋突起部の骨 㳄骨腯により閏口障審をきたした 2 例. 日口外 誌 29: 507-513 1983.

3）伊藤信明，大津匡志，他：下勔筋突起部の骨㳄 骨腫一自匼例ならびに文献的考察. 日口外誌 27: 863-872 1971.

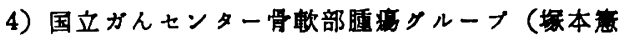

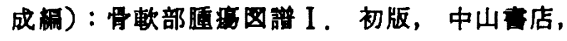
京都, 1972, 18頁.

5）日本整形外科学会，骨㳄部連场委員会編：整形 外科・病理 要性骨腄㾜取り报い規䄪. 金原出 版, 東京, 1982, 9-16頁.

6) Schackelford, R.T. and Brown, W.H.: Osteochondroma of the coronoid process of the mandible. Surgery Gynecology and Obstetrics 77: 51-54 1943.

7) Brandt, K.: Deformation de l'appopyse coronoid du maxillaire inferieur. Acta Orthop Scand 14: 219-224 1943.

8) Hallam, J.W.: Exostosis of the coronoid process of the mandible and true joint formation with zygomatic arch. Brit J Surg 34: 432-433 1947.

9) Schackelford, R.T. and Brown, W.H.: Restricted jaw motion due to osteochondroma of the coronoid process. J Bone Joint Surg 31-A: 107-114 1949.

10) Rowe, N.L.: Bilateral developmental hyperplasia of the mandibular coronoid process. A report of two cases. Brit J Oral Surg 1: 90-104 1952.

11) Brailsford, J.F.: An unusual osteochondroma from the coronoid process of the mandible. Brit J Radio 25: 555-556 1952.

12) Holmes, F.H.: Mandibular block by osteochondroma of the coronoid process. Radiology 67: 578-581 1956. 
13) Dingman, R.O. and Natig, P.: Reduced mandibular motion due to osteochondroma of the mandible. Am J Surg 94: 907-910 1957.

14) Levine, M.H. and Chessen J.: Osteochondroma of the coronoid process of the mandible. Report of a case and review of the literature. New England J Med 257: 3743761957.

15) Van Zile, W.N. and Johnson, W.B.: Bilateral coronoid process exostosis stimulating partial ankylosis of the temporomandibular joint. J Oral Surg 15: 72-77 1957.

16) Antoni, A.A., Brown, A., et al.: Osteochondroma of the coronoid process of the mandible. Report of case. J Oral Surg 16: 5145171958.

17) Pap, G. and Friedman, E.: Restricted mandibular movements due to osteochondroma of the coronoid process. Brit J Plast Surg 11: 167-173 1958.

18) Shira, R.B. and Lister, R.L.: Limited mandibular motion due to enlargement of the coronoid process. J Oral Surg 16: 183-191 1952.

19) Lewars, P.H.D.: Osteoma of the mandible. Brit J Plast Surg 12: 277-283 1959.

20) Lebo, C.P.: Osteochondroma of the mandibular coronoid process. Laryngoscope 71: 814-822 1961.

21) Mohnac, A.M. and Force Base, L.A.: Bilateral coronoid osteochondromas. J Oral Surg Anaesth. \& Hosp D Serv 20: 500-506 1962.

22) Lyon, L.Z. and Sarnat, B.G.: Limited opening of the mouth caused by enlarged coronoid process. J Amer Dent Ass 67: 6446501963.

23) Allan, M.B. and Reid, W.H.: Unilateral exostosis of coronoid process of the mandible. Brit J Oral Surg 5: 20-24 1967.

24) Fitzpatrick, B.M.: Bilateral hyperplasia of the mandibular coronoid process. Oral Surg 29: 184-190 1970.

25) Mayer, R.A.: Osteochondroma of coronoid process of mandible. J Oral Surg 30: 2973001972.

26）西嶋克巳，藤井康博，他：左側下频骨筋突起の 外骨腫に由来した開口障客の1例. 日口外誌 18: 59-65 1972.

27) Allan, J.H., Path, M.R.C., et al.: Osteochondroma of the mandible. Oral Surg 37: 556-565 1974.

28) Cooper, J.C. and Lawrence, D.F.: Coronoid osteochondroma presenting as a coronozygomatic ankylosis. A case report. Brit J
Oral Surg 6: 99-102 1974.

29) James, R.B., Alexander, R.W., et al.: Osteochondroma of the mandibular coronoid process. Report of a case. Oral Surg 37: 1891951974.

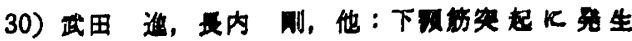
し，高度の䁌口它を来たした Osteochondroma の 1 湖。 日办化 21: 580-586 1975.

31) Rawon, Y., Horowitz, I., et al.: Osteochondroma of the coronoid process of the mandible. Oral Surg 43: 692-697 1977.

32) Hecker, R. and Corwin, J.O.: Bilateral coronoid hyperplasia; review of the literature and report of case. J Oral Surg 38: 606-608 1980.

33) Javid, B.: Unilateral hyperplasia of the coronoid process of mandible. Int J Oral Surg 10: 145-147 1981.

34) Lucaya, J., Herrera, M., et al.: Unilateral hyperplasia of the coronoid process in a child. A case of a restricted opening of the mouth. Radiology 144: 5281982.

35) Tucker, M.R., Guilford, W.B., et al.: Coronoid process hyperplasia causing restricted opening and facial asymmetry. Oral Surg 58: 130-132 1984.

36) Walker, D.G.: Benign nonodontogenic tumon of the jaws. J Oral Surg 28: 39-57 1970.

37) Jaffe, H.L.: Tumors and tumorous condition of the bone and joints. Lst Ed, Lea \& Febiger, Philadelphia, 1958, p 143.

38) Thoma, K.H. and Goldman, H.M.: Oral Pathology. 5th Ed, Mosby Co, St Louis, 1960, p 1255.

39) Mils, A.E.W.: Chondrosarcoma of the maxilla. Brit Dent J 88: 257-262 1950.

40) Lichtenstein, L.: Bone Tumors. 4 th Ed, Mosby Co, St Louis, 1972, p 17.

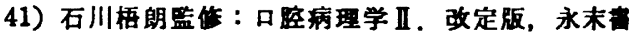
店, 京都, 1982, 150頁.

42) Gesichter, C.F. and Copeland, M.M.: Tumors of Bone. 3 rd Ed, JB Lippincott Co, Philadelphia, 1949, p 37, 77.

43) Weinman, J.P. and Sicker, H.: Bone and Bones. 2 nd Ed, Mosby Co, St Louis, 1955, p 377-386.

44) Kark, W.: Tumors of Bone. John Wright \& Sons, Bristol, 1969, p 10.

45) Hutchinson, A.C.: Tumors arising in tissue of mesenchymal origin. In Dental and Oral X-ray Diagnosis. E \& S. Livingstone, London, 1954, p 476-480.

46) Uhler, I.V.: Massive osteoma of the mandible. Oral Surg 10: 243-246 1957.

47) Schultz, L.W., Vazirani, S. J., et al.: Unila- 
teral hyperplasia and exostosis of the mandibular condyle. A clinical syndrome. Oral Surg 13: 387-395 1960.

48) Allan, J.H., Path, M.R.C., et al.: Osteochondroma of the mandible. Oral Surg 37: 5565651974.

49) Sanders, B., McKelvy, B.: Osteochondromatous exostosis of the condyle. J Am Dental Assoc 95: 1151-1153 1977.

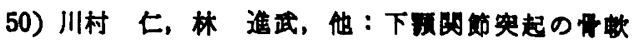

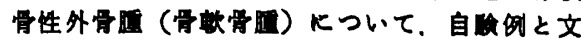
献的考莫. 日外誌 24：1165-1174 1978.

51) Kaneda, T., Torii, S., et al.: Giant osteo- chondroma of the mandibular condyle. J Oral Maxillofacial Surg 40: 818-821 1982.

52) Mark, R.B., Carlton, D.M., et al.: Osteochondroma of the mandibular condyle. Report of the case with 10-year follow up. Oral Surg 58: 30-32 1984.

53) Bruce, R.A. and Hayward, J.R.: Condylar hyperplasia and mandibular asymmetry. $\mathbf{A}$ review. J Oral Surg 26: 281-290 1968.

54) Blomquint, K. and Hogeman, K.E.: Benign unilateral hyperplasia of the mandibular condyle. Report of eight cases. Acta Chirur Scand 126: 414-426 1963. 